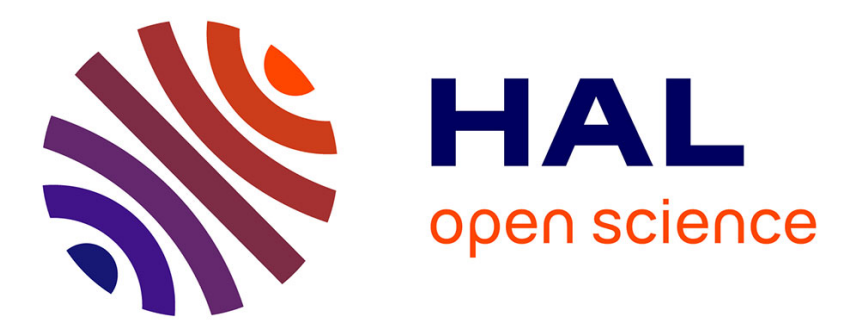

\title{
Pooling biodiversity offsets to improve habitat connectivity and species conservation
}

Simon Tarabon, Thierry Dutoit, Francis Isselin-Nondedeu

\section{To cite this version:}

Simon Tarabon, Thierry Dutoit, Francis Isselin-Nondedeu. Pooling biodiversity offsets to improve habitat connectivity and species conservation. Journal of Environmental Management, 2021, 277, pp.111425. 10.1016/j.jenvman.2020.111425 . hal-02956444

\section{HAL Id: hal-02956444 \\ https://hal.science/hal-02956444}

Submitted on 19 Nov 2020

HAL is a multi-disciplinary open access archive for the deposit and dissemination of scientific research documents, whether they are published or not. The documents may come from teaching and research institutions in France or abroad, or from public or private research centers.
L'archive ouverte pluridisciplinaire HAL, est destinée au dépôt et à la diffusion de documents scientifiques de niveau recherche, publiés ou non, émanant des établissements d'enseignement et de recherche français ou étrangers, des laboratoires publics ou privés. 


\title{
Pooling biodiversity offsets to improve habitat connectivity and species conservation
}

\author{
Simon Tarabon ${ }^{\mathrm{a}, \mathrm{b}, *}$, Thierry Dutoit ${ }^{\mathrm{b}}$, Francis Isselin-Nondedeu ${ }^{\mathrm{b}, \mathrm{c}}$ \\ ${ }^{a}$ Soberco Environnement, Chemin du Taffignon, 69630, Chaponost, France \\ ${ }^{\mathrm{b}}$ Institut Méditerranéen de Biodiversité et Ecologie, UMR CNRS-IRD, Avignon Université, Aix-Marseille Université, IUT d'Avignon, 337 chemin des Meinajariés, Site \\ Agroparc BP 61207, 84911, Avignon, cedex 09, France \\ c Département Aménagement et Environnement École Polytechnique de l'Université de Tours, UMR CNRS 7324 CITERES, 33-35 Allée Ferdinand de Lesseps, 37200, \\ Tours, France
}

\section{A R T I C L E I N F O}

\section{Keywords:}

Biodiversity offsets

Mitigation hierarchy

Offset efficiency

Habitat connectivity

Graph theory

\begin{abstract}
A B S T R A C T
Land developers can apply biodiversity offsetting in different ways, from a project-by-project approach to a pooled and proactive approach, this latter appearing to provide greater advantages both in terms of implementation and of the No Net Loss objective. Incorporating landscape connectivity into the mitigation hierarchy is commonly recommended, but the benefits of pooling and anticipating offsets have never really been demonstrated from modeling approaches. Here, we compare connectivity gains from two different offsetting scenarios, when interconnections at offset sites are taken and not taken into account. Assuming that gains can be increased by optimizing the location of offsets, we identified sites where biodiversity offsetting generates the greatest ecological gains in habitat connectivity. The method was applied to a study case in the suburbs of Lyon (Southern France) using several representative species and the landscape functional connectivity model Graphab. Pooling biodiversity offsets led to additional gains in overall habitat connectivity of $+103 \%$ on average, which we show can be further improved $(+8 \%)$ by using a patch addition process available in Graphab to plan spatially and ecologically coherent offsetting areas. Pooling and anticipating biodiversity offsets in this way can help preserve the biodiversity and the functionality of natural environments at the territorial scale.
\end{abstract}

\section{Introduction}

Biodiversity offsetting is increasingly used worldwide (Maron et al., 2018) to mitigate biodiversity losses caused mainly by human activities and land cover changes that result in natural habitat loss and fragmentation (Fahrig, 2017; Newbold et al., 2016). Compensation for the negative impacts on biodiversity related to the loss and degradation of species and habitats is provided by improving ecological conditions elsewhere (Gelcich et al., 2017), the goal being to achieve No Net Loss (NNL) of biodiversity (Maron et al., 2016; Simmonds et al., 2019). Offsetting is the third step of the so-called mitigation hierarchy, in which ecological damage is first avoided and then reduced (Bull et al., 2016; Kiesecker et al., 2010). Biodiversity offset can take the form either of concrete action like ecosystem restoration or of protection (avoidance of future habitat degradation or loss of biodiversity; Maron et al., 2012).

In general, the goal of biodiversity offsetting is to counterbalance losses attributable to a given impact at a given location. One of the main criticisms regarding this process is that in most cases it is not designed to decrease biodiversity loss, but only to allow averted loss to count as a biodiversity gain (Kormos et al., 2014; Moilanen and Laitila, 2016). Moreover, biodiversity offsetting is only applied to certain components of biodiversity (Bezombes et al., 2018; Carreras Gamarra et al., 2018) and does not thoroughly address, for instance, issues related to biodiversity at spatial scales larger than the impacted site or the offset sites (Kiesecker et al., 2010). Landscape connectivity is not a primary concern in biodiversity offsetting design (Bergsten and Zetterberg, 2013; Bigard et al., 2017; Kujala et al., 2015). In fact, biodiversity offsetting is generally applied in a project-by-project approach where little effort is made to ensure that the offset areas chosen provide the greatest connectivity benefit (Bigard et al., 2017; Persson et al., 2015). Yet connectivity appears to be a key factor in increasing the chances of offset success (Scolozzi and Geneletti, 2012; van Teeffelen et al., 2014). Landscape heterogeneity and habitat connectivity affect species movements, playing an important role in determining the likelihood of

\footnotetext{
* Corresponding author. Soberco Environnement, Chemin du Taffignon, 69630, Chaponost, France.

E-mail addresses: simon.tarabon@yahoo.fr, simon.tarabon@imbe.fr, simon.tarabon@yahoo.fr, simon.tarabon@imbe.fr (S. Tarabon).
} 
species persistence and richness (Crooks and Sanjayan, 2006; Fahrig, 2017; Hooftman et al., 2016). Connectivity influences in particular how much of offsets is utilized (Hodgson et al., 2011).

In the light of recurrent failures in biodiversity offsetting implementation (see Bezombes et al., 2019; May et al., 2017; Weissgerber et al., 2019), there is growing evidence of the benefits of including landscape connectivity into the mitigation hierarchy (Dalang and Hersperger, 2012; Tarabon et al., 2019b, 2020). A territorial-scale conservation strategy seems to further increase these benefits. To that end, biodiversity offsetting can be implemented through mitigation banking, where ecological restorations are generated prior to any impact from projects, and then purchased by future land developers (Bekessy et al., 2010; Boisvert, 2015; Levrel et al., 2017). This is a common system in some countries but new in France, where it was installed by the 2016 Biodiversity Act (Loi ${ }^{\circ}$ 2016-1087 pour la reconquête de la biodiversité, de la nature et des paysages). By anticipating future damage, mitigation banking helps avoid temporary losses of biodiversity while restoring large functional areas which have greater chances of ecological efficiency (Bull and Strange, 2018; Moreno-Mateos et al., 2012). However, the gap between measures and impacts has drawn some criticism (Kiesecker et al., 2009). Another form of biodiversity offsetting organization is the so-called "pre-identified" offsetting emerging in the US, Germany, or France (Wende et al., 2018). In this approach, offsetting is implemented during or after the impacts, as in a case-by-case approach, but is also used to develop and manage green corridors allowing the movements that ensure species' survival.

However, despite recent studies which have used spatial prioritization to demonstrate the value of locating biodiversity offsets in different parts of the landscape (e.g., McKenney and Kiesecker, 2010; Moilanen, 2013) and others which have focused on incorporating connectivity (e. g., Tambosi et al., 2014), the territorial organization of biodiversity offsetting and the benefits generated by their localization and pooling are poorly considered in studies, whatever the form chosen by land developers (Scolozzi and Geneletti, 2012). Yet, organizing and pooling offsets are key to improving and reaping biodiversity offsets benefits (Bigard et al., 2020; Tarabon et al., 2020), particularly in agricultural and suburban areas where the pressure of urbanization is relatively strong and where the landscape usually suffers from fragmentation (Haverland and Veech, 2017).

To better address these biodiversity offsetting issues, a landscape connectivity approach needs to be taken. Effective modeling tools have been developed to assess landscape connectivity (Kool et al., 2013), including models based on graph theory like Graphab (Foltête et al., 2012) or Conefor (Saura and Torne, 2009), a mathematical tool for analyzing functional connectivity in ecological conservation (Correa Ayram et al., 2016; Foltête, 2019). They provide operational models of ecological networks due to their good compromise between information yielded and data requirements (Foltête, 2019; Saura and de la Fuente, 2017). Landscape graphs measure landscape connectivity with reference to the spatial configuration of the patches, the nature of the landscape matrix they form, and the dispersal capacities and ecological requirements of species (Rayfield et al., 2011). They have already proved useful in various aspects of planning for biodiversity conservation (Foltête, 2019), particularly in the mitigation hierarchy (see for example Bergès et al., 2020; Mimet et al., 2016; Tarabon et al., 2019b).

In this paper, we address the following question: Can the pooling and the spatial organization of biodiversity offsets increase the efficiency and effectiveness of planning for biodiversity conservation? We hypothesize that pooling biodiversity offsets can have a cumulative beneficial effect on habitat connectivity. We also assume that these gains could be increased by optimizing the biodiversity offsets location. Different offsets located in the same study area were assessed for habitat connectivity gains generated by their pooling or networking, as compared to a scenario where the same offsets were not considered as interconnected. We performed habitat connectivity analysis using Graphab (Foltête et al., 2012) on several species from different taxonomic groups, in a case study located in the suburbs of Lyon, in France.

\section{Methods}

\subsection{Study site}

The study was carried out in the suburbs of Lyon, France, an area covering $78 \mathrm{~km}^{2}$ and already heavily urbanized (56\%). It is subject to urban pressure from metropolitan Lyon's territorial dynamism, which particularly impacts the semi-natural and agricultural habitats representing $28 \%$ and $16 \%$ of the study area, respectively.

We identified 22 biodiversity offsetting sites belonging to local authorities from a local study conducted by an engineering consultant, based on their potential gains in terms of habitats and species (Soberco Environnement, 2019). Gains were assessed for several species (terrestrial mammals, birds, amphibians, chiropterans, etc.), mitigation measures generally having multi-species objectives (Rayfield et al., 2016; Santini et al., 2016).

The biodiversity offset sites are located on average $620 \mathrm{~m}$ from neighboring offset sites (Fig. 1) and vary in size between 0.5 and 3.0 ha (mean of 1.4 ha). At each offset site, we defined and planned ecological measures for diversifying habitats and improving the ecological connectivity of the study area. These ecological measures were aimed at various species linked to hedgerows, groves and wood-fringes and involved either the creation of hedgerows, groves and grasslands, or the development of regulatory protection. Our method of selecting biodiversity offset sites and defining ecological principles is in line with the usual procedure followed by developers in a project-by-project approach. Cost-efficiency influences offsetting design, and the simplest ecological measures (access to land, planning principles) are generally sought (Pouzols et al., 2012). The ecological quality of offset sites is not really defined (Weissgerber et al., 2019), thus minimizing the extent of biodiversity offset implementation (Persson et al., 2015).

\subsection{Target species}

Landscape graphs model the ecological networks of single species by focusing on well-identified habitat. However, the development of efficient mitigation hierarchy strategies requires measures that can benefit various species, including both rare and more common species, with various habitat preferences. Here, we addressed multi-species conservation goals by identifying several representative species of different taxonomic groups linked to forest areas and particularly affected by development projects in this area (Soberco, 2019). Four target species were selected: 1 ) the red squirrel (Sciurus vulgaris), a terrestrial mammal species that is an indicator of well-preserved woodland and forest in the landscape (Avon and Bergès, 2016; Fey et al., 2016; Hämäläinen et al., 2018); 2) the spotted flycatcher (Muscicapa striata), a typical bird species of edges and, in France, old parks and urban and peri-urban gardens (Rogeon and Sordello, 2012; Stevens et al., 2007); 3) the lesser noctule (Nyctalus leisleri), a chiropteran species that is a good indicator of the quality of the urban and peri-urban landscape matrix and especially the presence of hedges and trees outside forests (Arthur and Lemaire, 2009); and 4) the fire salamander (Salamandra salamandra), an amphibian species widely recognized as particularly sensitive to habitat loss and fragmentation, which exposes it to risk from traffic collisions (Duguet et al., 2003; Thirion et al., 2014). Although dependent on forest habitats, these species have different habitat preferences and dispersal capacities that we identified from the biological literature (Table 1).

\subsection{Land-use and land-cover data}

Data used to map the ecological value of landscape and simulate ecological networks were extracted from available national databases in order to produce a relevant $5 \mathrm{~m}$-resolution raster map. This allows one to 
a)

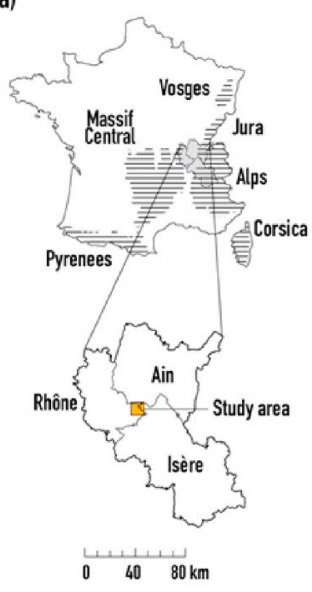

b)

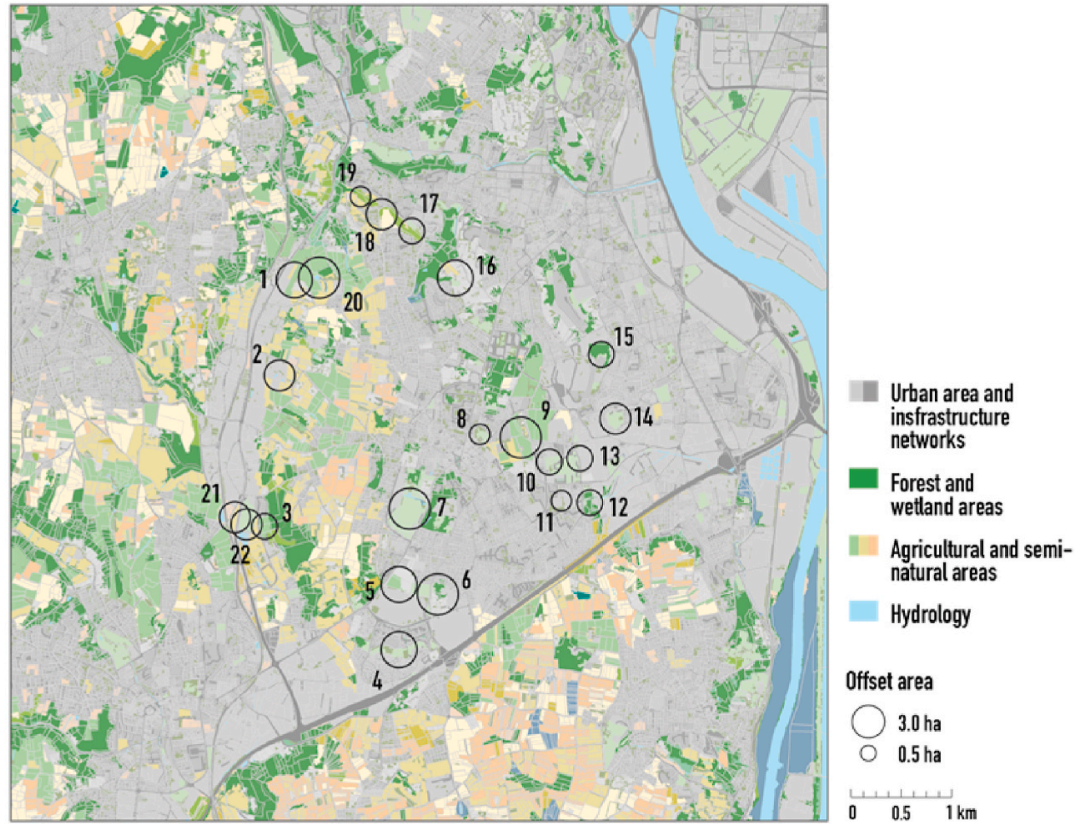

Fig. 1. Location of the study area (suburbs of Lyon) at the national and regional scale (a) and the biodiversity offsetting sites considered in this study (b).

Table 1

Ecological requirements of the representative species across their habitats (land-cover and land-use; LULC) and minimum surface area ( $\mathrm{S}_{\text {min }}$ ) and their maximum dispersal capacity $\left(D_{\max }\right)$. LULC categories were: 1 ) urban parks, 2) hedges and bushes, (3) coniferous forests, 4) broad-leaved forests, 5) mixed forests, 6) trees outside forests, 7) other forests (not determined), 8) street trees, 9) natural grasslands, 10) temporary pastures, 11) moors and heathlands, 12) tree plantations, 13) wetland areas, 14) watercourses, 15) other urban areas, 16) other agricultural areas, 17) discontinuous urban fabric, 18) densely built-up urban areas, 19) industrial and commercial areas, 20) ports, 21) railways and associated land, 22) major transport infrastructures, 23) secondary roads. LULC types were converted into resistance classes and cost values $(1-10,000)$ to identify those that facilitate or constrain species movements.

\begin{tabular}{|c|c|c|c|c|c|}
\hline \multicolumn{2}{|l|}{ Taxonomic group } & \multirow{2}{*}{$\frac{\text { Terrestrial mammals }}{\text { Red squirrel (Sciurus vulgaris) }}$} & \multirow{2}{*}{$\frac{\text { Birds }}{\text { Spotted flycatcher (Muscicapa striata) }}$} & \multirow{2}{*}{$\begin{array}{l}\text { Chiropterans } \\
\begin{array}{l}\text { Lesser noctule (Nyctalus } \\
\text { leisleri) }\end{array}\end{array}$} & \multirow{2}{*}{$\begin{array}{l}\text { Amphibians } \\
\text { Fire salamander (Salamandra } \\
\text { salamandra) }\end{array}$} \\
\hline Species & & & & & \\
\hline $\begin{array}{l}\text { Habitats } \\
\text { (LULC types) }\end{array}$ & & $2,3,4,5,6,7$ & $1,2,6$ & $4,5,6,13$ & $4,5,6,13$ \\
\hline $\mathrm{D}_{\max }(\mathrm{m})$ & & 4000 & 1200 & 12,000 & 700 \\
\hline $\mathrm{S}_{\min }$ (ha) & & 0.5 & 0.3 & 0.5 & 0.3 \\
\hline LULC types per & 1 & $3,4,5,6$ & 1,6 & $4,5,6,13$ & $4,5,6,13$ \\
\hline \multirow[t]{5}{*}{ cost values } & 50 & $2,7,9,11,12,13$ & $2,9,10,11,12,13,17$ & $\begin{array}{l}1,2,3,7,8,9,10,12 \\
14,17\end{array}$ & $2,7,8,9,11,12$ \\
\hline & 100 & $1,8,10,17$ & $8,14,15,16,19,20,21,23$ & $11,21,23$ & $1,10,17$ \\
\hline & 400 & $15,16,21,23$ & $3,4,5,7$ & $15,16,19,22$ & $3,15,16,21,23$ \\
\hline & 800 & 18,19 & 18,22 & 18,20 & 14 \\
\hline & 10,000 & $14,20,22$ & - & - & $18,19,20,22$ \\
\hline References & & $\begin{array}{l}\text { Fey et al. (2016); Hämäläinen } \\
\text { et al. (2018) }\end{array}$ & $\begin{array}{l}\text { Géroudet et al. (1980); Rogeon and Sordello } \\
\text { (2012); Stevens et al. (2007) }\end{array}$ & $\begin{array}{l}\text { Arthur and Lemaire } \\
\text { (2009) }\end{array}$ & $\begin{array}{l}\text { Duguet et al. (2003); Gasc } \\
\text { et al. (1997) }\end{array}$ \\
\hline
\end{tabular}

take into account the small habitat characteristics, which can be very important for some taxa (Le Roux et al., 2017; Wintle et al., 2019). Forests, hedges, bushes, moor, heathland, tree plantations and hydrography are taken from BD TOPO ${ }^{\circledR}$ provided by the French National Geographical Institute (IGN), crop areas and pastures from the French Record of Agricultural Plots (RPG), and urban areas, urban parks, ports and transport networks from the European Urban Atlas provided by the Global Monitoring for Environment Security project. We also extracted street trees, wetland areas and inventory and protection areas from the available local database of metropolitan Lyon. We selected 22 categories of land-use and land-cover (LULC) data expected to be a priori the most relevant to the ecological and biological requirements of the selected species (Table 1).

\subsection{Landscape connectivity analysis}

We represented habitat networks from landscape graphs where habitats patches appear as nodes and the potential movements of individuals between patches appear as links connecting pairs of nodes (Urban et al., 2009). We used Graphab (version 2.4; Foltête et al., 2012, see http://thema.univ-fcomte.fr/productions/graphab/) to model habitat networks and then conduct the connectivity analysis.

First, we assumed that the capacity of a habitat patch depends not only on its size, but also on the quality of the surrounding environment (i.e., its ability to provide conditions favorable for occurrence of individuals) (Häkkilä et al., 2018; Hooftman et al., 2016), especially important for species with low mobility (see for example Fuentes-Montemayor et al., 2017). Therefore, a map of landscape ecological values was produced based on certain ecologically relevant criteria identified from the literature. We identified several indicators related to landscape structure, nature of land-use and cover, and inventory and protection areas. The ecological value of landscape relies not only on LULC characteristics (including different biodiversity potential factors such as nature, inventory and protection areas, and ecological 
functionality level), but also on the composition and configuration of the landscape (such as density, rarity, or shape of habitats; Bigard et al., 2020, Table 2).

A rare environment is considered important and requires special attention (CRENAM, 2011). We thus considered, through an indicator called "LULC rarity", the proportion of each land-cover type (except for urban areas) relative to the total area of natural and semi-natural areas.

\section{Table 2}

Indicators related to landscape structure and nature of land-use and land-cover (LULC) to assess the landscape contribution to biodiversity of each cell at 5-m resolution. ENS, ORE, APPB, ZNIEFF, EBC and EVV are France-specific regulatory tools for the protection of natural environments (UICN, 2013, 2016 Biodiversity Act).

\begin{tabular}{|c|c|c|}
\hline Indicators (and literature associated) & Categories & Value \\
\hline \multirow[t]{4}{*}{ LULC rarity (CRENAM, 2011) } & High: $<1 \%$ & 1 \\
\hline & Medium: 1 à $5 \%$ & 0.6 \\
\hline & Low: $>5 \%$ & 0.3 \\
\hline & $\begin{array}{l}\text { Not affected: } \\
\text { water bodies and } \\
\text { courses }\end{array}$ & 0 \\
\hline $\begin{array}{l}\text { LULC diversity (CRENAM, 2011; McGarigal and } \\
\text { Cushman, 2005) }\end{array}$ & High to low & 0 to 1 \\
\hline \multirow[t]{5}{*}{$\begin{array}{l}\text { Potential for biodiversity (Kujala et al., 2015; } \\
\text { Letourneau and Thompson, 2014) }\end{array}$} & $\begin{array}{l}\text { High: natural } \\
\text { grasslands, } \\
\text { broad-leaved and } \\
\text { mixed forests, } \\
\text { trees outside } \\
\text { forests, moors } \\
\text { and heathlands, }\end{array}$ & 1 \\
\hline & $\begin{array}{l}\text { Medium to high: } \\
\text { wetland areas, } \\
\text { coniferous } \\
\text { forests, other } \\
\text { forests, } \\
\text { temporary } \\
\text { pastures, hedges } \\
\text { and bushes }\end{array}$ & 0.75 \\
\hline & $\begin{array}{l}\text { Medium: tree } \\
\text { plantations, } \\
\text { urban parks }\end{array}$ & 0.50 \\
\hline & $\begin{array}{l}\text { Low: street trees, } \\
\text { crop areas, other } \\
\text { agricultural } \\
\text { areas, water } \\
\text { bodies, water } \\
\text { courses }\end{array}$ & 0.25 \\
\hline & $\begin{array}{l}\text { Very low: } \\
\text { artificial areas }\end{array}$ & 0 \\
\hline \multirow[t]{4}{*}{$\begin{array}{l}\text { French inventory and protection areas (Gray et al., } \\
\text { 2016; Le Saout et al., 2013) }\end{array}$} & $\begin{array}{l}\text { Major } \\
\text { contribution: } \\
\text { Espace naturel } \\
\text { sensible (ENS), } \\
\text { Obligation Réelle } \\
\text { Environnementale } \\
\text { (ORE), Arrêté } \\
\text { Préfectoraux de } \\
\text { Protection de } \\
\text { Biotope (APPB) }\end{array}$ & 1 \\
\hline & $\begin{array}{l}\text { Important } \\
\text { contribution: } \\
\text { Zones Naturelles } \\
\text { d'Intérêt } \\
\text { Écologique } \\
\text { Faunistique et } \\
\text { Floristique } \\
\text { (ZNIEFF) }\end{array}$ & 0.50 \\
\hline & $\begin{array}{l}\text { Significant } \\
\text { contribution: } \\
\text { Espaces Classés } \\
\text { Boisés (EBC), } \\
\text { Espaces végétalisés } \\
\text { à valoriser (EVV) }\end{array}$ & 0.25 \\
\hline & Others & 0 \\
\hline Form complexity (Crossman et al., 2007) & High to low & 0 to 1 \\
\hline Core area (McGarigal and Cushman, 2005) & High to low & 0 to 1 \\
\hline
\end{tabular}

Moreover, high diversity or local wealth of habitats is considered beneficial for biodiversity, particularly when habitats are homogeneous in size (CRENAM, 2011; McGarigal and Cushman, 2005). The richness and homogeneity of areas was captured here through an indicator called "LULC diversity" in summary form by the Shannon Index (Shannon, 1948) using Land Facet Corridor Designer (Beier and Brost, 2010). LULC offers differing potential for the development or maintenance of biodiversity (Kujala et al., 2015; Letourneau and Thompson, 2014). We prioritized the different types of land-cover according to their biodiversity potential. The ecological interest of natural environments is also reflected in protection, inventory, and management measures (Gray et al., 2016; Le Saout et al., 2013), which we defined from the various protection tools in France (UICN, 2013); 2016 Biodiversity Act). Ecotones, too, are very important in biological processes and were incorporated through an indicator called "Form complexity", the Fractal Dimension Index (FRAC; Eq. (1)) for a landscape element $i$ (according to LULC) given by the following formula (Crossman et al., 2007):

$F R A C=\frac{2 \ln \left(0.25 \times p_{i}\right)}{\ln a_{i}}$

where $a_{i}$ is the area and $a_{i}$ the perimeter of the landscape element.

Finally, we considered the ratio between the "core area" of landscape elements, defined by a buffer zone $(20 \mathrm{~m})$, and its total area. This Core Area Index completes the form complexity index.

As a preliminary, we tested collinearity and estimated the effect of multicollinearity among variables with the variance inflation factors (VIF). A stepwise approach was used, where a VIF is calculated with usdm package for each variable, which is then selected if values are below the threshold (VIF < 10; Naimi et al., 2014; R Team, 2017). For each indicator, we defined in each cell a value between 0 and 1 (continuous or ordinal value depending on the indicators). Then, we produced a 5-m resolution raster map by combining indicator values. The value of each cell is here the average of each indicator value using a uniform weighting. The calculation was performed for each connectivity model involving changes in land-use and therefore in the value of indicators.

Although this type of approach cannot fully reveal the ecological reality, the aim here was to prioritize landscape elements based on ecologically relevant criteria, so as to weight habitat areas according to habitat quality for the following step involving the connectivity analysis.

Next, we prepared a 5-m resolution raster map by combining different vector data. A landscape graph was generated for each representative species. The nodes of landscape graphs were defined according to the land-cover categories favored as habitat by each species, based on the literature, as the minimal area of nodes (Table 1). The LULC categories were assigned to six resistance classes based on the species' ability to move within them: highly suitable, suitable, neutral, unfavorable, highly unfavorable or barrier to animal movement (Mimet et al., 2016), with cost values from 1 (highly suitable) to 10,000 (barrier) (Tarabon et al., 2019a, Table 1).

We used the extrapolation of the local metric of interaction flux IF (Eqs. (2) and (3)) to evaluate the potential accessibility of any point (i.e. pixel) to the overall study area.

$I F=\sum_{j=1}^{n} a_{i} a_{l} p_{i j}$

where $n$ is the total number of patches, and $a_{i}$ and $a_{j}$ are attributes of the nodes of landscape graphs $i$ and $j$. Node attributes correspond to the quality-weighted habitat area we considered here in the connectivity calculation, as an indicator of incoming or outgoing flows of each habitat patch. For instance, 1 ha of habitat amounts to 1 ha if its average ecological importance value is 1 , while the same habitat area amounts to 0.5 ha if its average ecological importance value is $0.5 . p_{i j}$ * is defined as the maximum product probability of all possible paths between patches $i$ 
and $j$ (including single-step paths). The product probability of a path (where a path is made up of a set of steps in which no patch is visited more than once) is the product of all the $p_{i j}$ belonging to each step in that path. If patches $i$ and $j$ are close enough, the maximum probability path will be simply the step (direct movement) between patches $i$ and $j\left(p_{i j}{ }^{*}=\right.$ $p_{i j}$ ). If patches $i$ and $j$ are more distant, the "best" (maximum probability) path would probably comprise several steps through intermediate stepping-stone patches yielding $p_{i j}{ }^{*}>p_{i j}$ (Saura and Pascual-Hortal, 2007). Here, the probability of connection between two patches was based on the least-cost distance between these two patches. Least-cost distance was transformed into probability of connection between patches $i$ and $j$ using a decreasing exponential function, as presented in the following Eq. (3):

$p_{i j}=e^{-\propto d_{i j}}$

where $\alpha$ is a cost-distance-decay coefficient: $\alpha$ is usually set so that $p_{i j}=$ 0.5 when $d$ corresponds to the median dispersal distance, or $p_{i j}=0.05$ when $d$ corresponds to the maximal distance dispersal (Saura and Pascual-Hortal, 2007).

The extrapolation of $I F$ relies on the assumption that individuals may be found outside habitat patches, although this is less likely than within habitat patches (Hirzel and Le Lay, 2008). For a given point, connectivity levels from several patches were attributed by summing the weighted values of $I F$ as follows (Eq. (4); Sahraoui et al., 2017):

$g I F_{i}=\sum_{j=1}^{n} I F_{j} \times w_{i j}$

where $g I F_{i}$ is the generalized value of $I F$ for point $i$, and $w_{i j}$ is the weighting of patch $j$ for point $i$. The weighting function is a decreasing exponential function, as presented in Eq. (2) below.

For each scenario tested (see below) in the connectivity analysis, we obtained a 5-m spatial resolution single-species map where potential of connectivity to the overall network is defined for each pixel.

\subsection{Methods of assessing habitat connectivity}

Two different methods were used here to calculate gains. The first, called "SC IND", entailed evaluating for each species the gains that each separate biodiversity offset provided. A model was built for each biodiversity offset and an aggregated single-species map was produced by considering for each cell the maximum value of gains generated. The second method, called "SC $\mathrm{ALL}_{\text {", }}$ entailed considering all the biodiversity offsets and their potential degree of connectivity. Overall landscape connectivity was estimated as the sum of gains for all cells according to the extrapolation of the local interaction flux index ( $\left.\sum \mathrm{gIF}\right)$. Overall gains from each scenario $\left(\mathrm{SC}_{\mathrm{i}}\right)$ were defined as the relative difference between the values from this scenario and initial state $\left(\Delta_{\mathrm{i}}\right)$. Then, we quantified the "additional" gains (AG) generated by the pooling of biodiversity offset as the relative difference between the gains provided under the two scenarios. Landscape connectivity being evaluated for each cell, we also spatialized the local variation (i.e. gains) in additional gains for each species.

\subsection{Optimizing the location of biodiversity offsets and habitat connectivity gains}

Finally, we determined the best locations to implement habitat patches and further improve gains in habitat connectivity. Cells corresponding to habitat patches of $5000 \mathrm{~m}^{2}$ were prioritized for each species by means of a cumulative patch addition process available in Graphab. In addition to the 22 initial biodiversity offset sites, we randomly defined (without regard to whether plots were public or private) 53 potential sites located on crop areas, meadows, and discontinuous urban areas (Fig. 2). For the sake of comparability, we included 22 offset sites

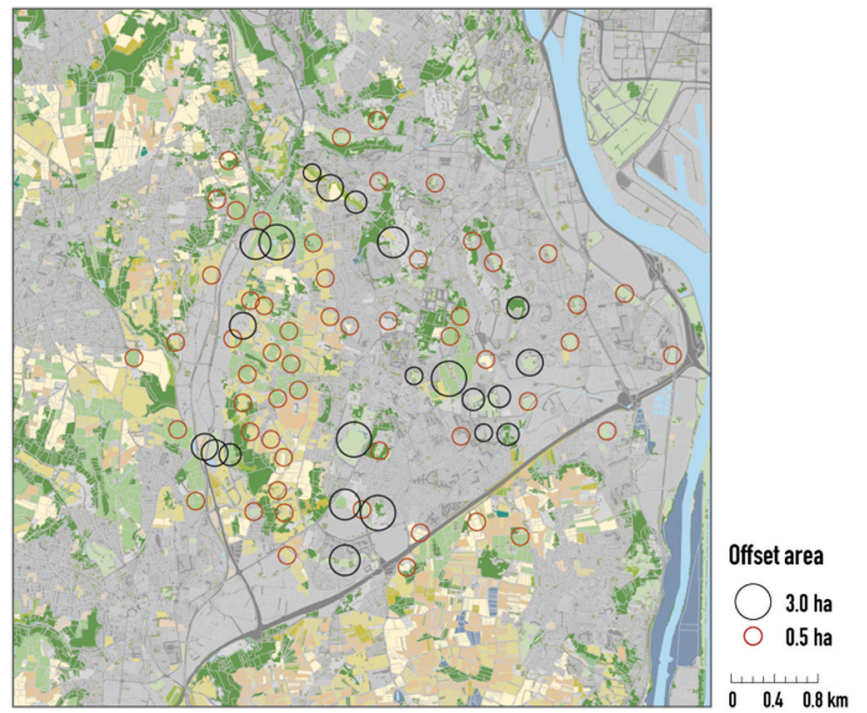

Fig. 2. Location of the 22 initial biodiversity offset sites (see Section 2.1, represented here by black circles) and the 53 additional biodiversity offset sites (represented by red circles) in the suburbs of Lyon used in the cumulative patch addition process available in Graphab to optimize habitat connectivity. (For interpretation of the references to colour in this figure legend, the reader is referred to the Web version of this article.)

considered previously. The stepwise procedure was as described in Foltête et al. (2014) and applied in previous studies (Clauzel et al., 2015; Mimet et al., 2016; Tarabon et al., 2019b). Once single-species prioritization maps were obtained, we overlaid them to identify the new habitat patches of benefit to all four species targeted, selecting the 25 most beneficial and assessing the gains generated by optimizing their location.

\section{Results}

\subsection{Mapping of ecological value}

The ecological value map of natural and semi-natural areas at the initial state is illustrated in Fig. 3. A high value indicates the highest possible ecological interest, while a low value shows zero or low

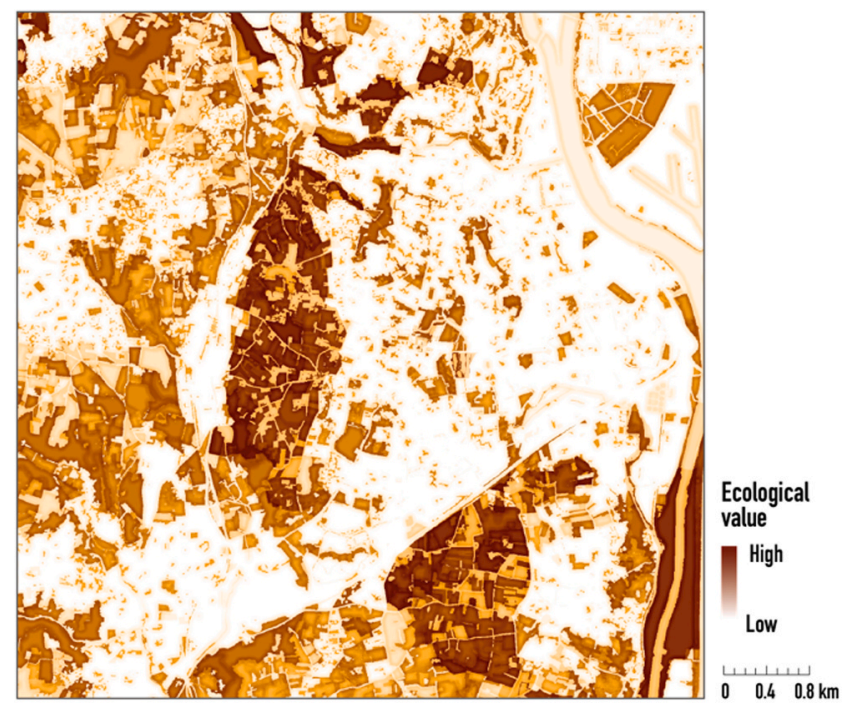

Fig. 3. Ecological value map at the initial state according to multi-criteria analysis in the suburbs of Lyon, Rhône valley, France. 
ecological importance. In this study case, ecological value is mainly attributed to natural or semi-natural areas preserved from urbanization, and inventory and protection areas.

\subsection{Assessment of biodiversity offsetting effects on habitat connectivity}

The results presented in Table 3 show different overall gains in habitat connectivity depending on whether biodiversity offsets were pooled $\left(\mathrm{SC}_{\mathrm{ALL}}\right)$ or not $\left(\mathrm{SC}_{\mathrm{IND}}\right)$. On average, habitat connectivity gains were $+0.84 \%$ for $\mathrm{SC}_{\mathrm{IND}}$ and $+1.76 \%$ for $\mathrm{SC}_{\mathrm{ALL}}$. Pooling biodiversity offsets led to additional gains in overall habitat connectivity of $+103.5 \%$ on average. Benefits were particularly strong for the terrestrial mammals, represented here by the red squirrel, with an increase of $+194 \%$. For amphibians (fire salamander), additional gains were 'only' $+32.1 \%$.

Next, by spatializing the additional gains for each species, we show the spatial extent of biodiversity offsets pooling benefits (Fig. 4).

\subsection{Optimizing the location of habitat patches}

The patch addition process highlighted the locations where the 25 new habitat patches generate the highest gain in connectivity. The results are shown in Fig. 5. Only 6 of the biodiversity offset sites identified with our method correspond to the initial offset sites (see Section 2.1), $i$. e. $27.3 \%$. Then, we estimated the new locations where biodiversity offset increased overall habitat connectivity compared to $\mathrm{SC}_{\mathrm{ALL}}$ by $+12.3 \%,+6.9 \%,+3.1 \%$ and $+9.5 \%$ for the red squirrel, the spotted flycatcher, the lesser noctule and the fire salamander, respectively.

\section{Discussion}

\subsection{Planning and pooling biodiversity offsets}

Our analysis points to the importance of biodiversity offset location and planning in biodiversity conservation. Using our study case, we demonstrated here how anticipating and pooling biodiversity offset sites can improve habitat connectivity for several representative species of different taxonomic groups (terrestrial mammals, birds, chiropterans, and amphibians). biodiversity offset sites have often been selected according to land availability, without considering the need to integrate them into ecological networks. We voluntary adopted this approach, usually criticized (Bigard et al., 2017; Kujala et al., 2015), for the purposes of comparison. It enabled us to show that gains can be further optimized if biodiversity offset sites are properly located. While this is commonly recommended, as in Hooftman et al. (2016) who suggested that conservation could be enhanced by strengthening connectivity, it has rarely been applied (but see Bergès et al., 2020; Tarabon et al., 2019b; Tarabon et al., 2020).

Several biodiversity offset sites (i.e. $\mathrm{n}^{\circ} 4$ to 6 and 10 to 15 ) were not located in areas of high ecological interest (sensus our ecological value map), and therefore greater biodiversity gains could have been expected (Weissgerber et al., 2019). However, in urban and peri-urban areas, fragmentation is relatively high. Despite the theoretical proximity of biodiversity offset sites, connectivity is not always improved, and a landlocked area is unlikely to be used by species. This is why landscape connectivity needs to be included in gain assessment for biodiversity offset sites and measures.

The gains from pooling biodiversity offsets varied here, appearing to depend on species' dispersal capacity. Additional gains were smaller for low mobility species (i.e. fire salamander), and for species with high dispersal capacity (i.e. lesser noctule) for whom the stepping stone (Saura et al., 2014) was probably less useful, although (Fuentes-Montemayor et al., 2017) pointed out that landscape elements are important for higher mobility species, in their case the bat. Here, the gains were greater for the two other species (i.e. red squirrel and spotted flycatcher), whose dispersal distances are 2-7 times greater than the average distance between biodiversity offset sites.

\subsection{Recommendations to stakeholders}

First, although our approach is based on a relatively small study area $\left(78 \mathrm{~km}^{2}\right)$, relevant in our local context, a wider landscape scale (from towns or municipalities to provinces or regions) could be relevant in the context of spatial biodiversity offsets planning (Bigard et al., 2017). Moreover, broader issues related to agricultural, urban, or economic development strategies could be considered.

Second, we showed here that the spatial organization of biodiversity offsets in habitat networks can enhance ecological connectivity, thereby increasing the chances of biodiversity offsets success. Nevertheless, gains depend on the plots used in the analysis, and we suggest that the analysis should not be limited to public plots as it is here, but extended to private land (see for instance Tarabon et al., 2020). Locating the most ecologically relevant biodiversity offsets in these plots can support ecological networks like the "green and blue corridors" (Chaurand et al., 2019), and their strategic position will lead to far greater ecological gains. We are aware that environmental and urban planners have little control over private land, which represent an operational constraint to implement biodiversity offsets (cost of acquiring lands, etc.). However, the modelling tools are only to test potential gains and to guide ecological, political and/or economical decisions. In some case, the cost-benefit can be significant and acquiring land as offset could eventually be more economical in the long-term than the ecological developments and management of several lands with low ecological gains on habitat connectivity. In addition, in order to facilitate the implementation of biodiversity offsets, we suggest to stakeholders to adopt a mixed approach, for instance considering private-public partnerships.

Then, while a multi-species approach (see for example Sahraoui et al., 2017) is important in planning of biodiversity offsets, since the challenges and impacts of development projects are not yet identified, planners should not rush into grouping species (i.e., habitat type favoring a wide range of species). Oversimplification can lead to failure to represent biodiversity in a pertinent manner, and thus to future failure to meet the NNL objective (Bekessy et al., 2010; Walker et al., 2009). Species' respective ecological requirements can generate disparities in the benefits from an offset that it is important to assess. Here, we tested the methodological framework on 4 representative species, but more species need to be assessed in operational studies.

Table 3

The sum of potential for connectivity to the overall network, according to the extrapolation of the local interaction flux index ( $\sum$ gIF), is calculated at the initial state $\left(\sum \mathrm{gIF}_{\mathrm{IS}}\right)$, assessing both gains from each individual biodiversity offset $\left(\sum \mathrm{gIF}_{\mathrm{IND}}\right)$ and gains from all offsets and their potential interconnections $\left(\sum \mathrm{gIF}_{\mathrm{ALL}}\right) . \Delta_{\mathrm{IND}}$ and $\Delta_{\mathrm{ALL}}$ are the relative difference between $\sum \mathrm{gIF}$ values at the initial state (IS) and from the two scenarios $\mathrm{SC}_{\mathrm{IND}}$ and $\mathrm{SC}_{\mathrm{ALL}}$, respectively. AG ("additional" gains) is the variation in gains generated by pooling biodiversity offsets.

\begin{tabular}{|c|c|c|c|c|c|c|}
\hline \multirow[b]{2}{*}{ Species } & \multirow{2}{*}{$\frac{\mathrm{IS}}{\sum \mathrm{gIF}_{\mathrm{IS}}}$} & \multicolumn{2}{|l|}{$\mathrm{SC}_{\mathrm{IND}}$} & \multicolumn{2}{|l|}{$\mathrm{SC}_{\mathrm{ALL}}$} & \multirow[b]{2}{*}{ AG } \\
\hline & & $\sum g \mathrm{IF}_{\mathrm{IND}}$ & $\Delta_{\mathrm{IND}}$ & $\sum \mathrm{gIF}_{\mathrm{ALL}}$ & $\Delta_{\mathrm{ALL}}$ & \\
\hline Red squirrel (Sciurus vulgaris) & $3.36 \times 10^{19}$ & $3.39 \times 10^{19}$ & $+0.89 \%$ & $3.45 \times 10^{19}$ & $+2.61 \%$ & $+194.0 \%$ \\
\hline Spotted flycatcher (Muscicapa striata) & $1.23 \times 10^{16}$ & $1.24 \times 10^{16}$ & $+0.92 \%$ & $1.26 \times 10^{16}$ & $+2.10 \%$ & $+128.1 \%$ \\
\hline Lesser noctule (Nyctalus leisleri) & $1.08 \times 10^{20}$ & $1.09 \times 10^{20}$ & $+0.94 \%$ & $1.10 \times 10^{20}$ & $+1.50 \%$ & $+59.8 \%$ \\
\hline Fire salamander (Salamandra salamandra) & $7.78 \times 10^{17}$ & $7.82 \times 10^{17}$ & $+0.62 \%$ & $7.84 \times 10^{17}$ & $+0.82 \%$ & $+32.1 \%$ \\
\hline
\end{tabular}



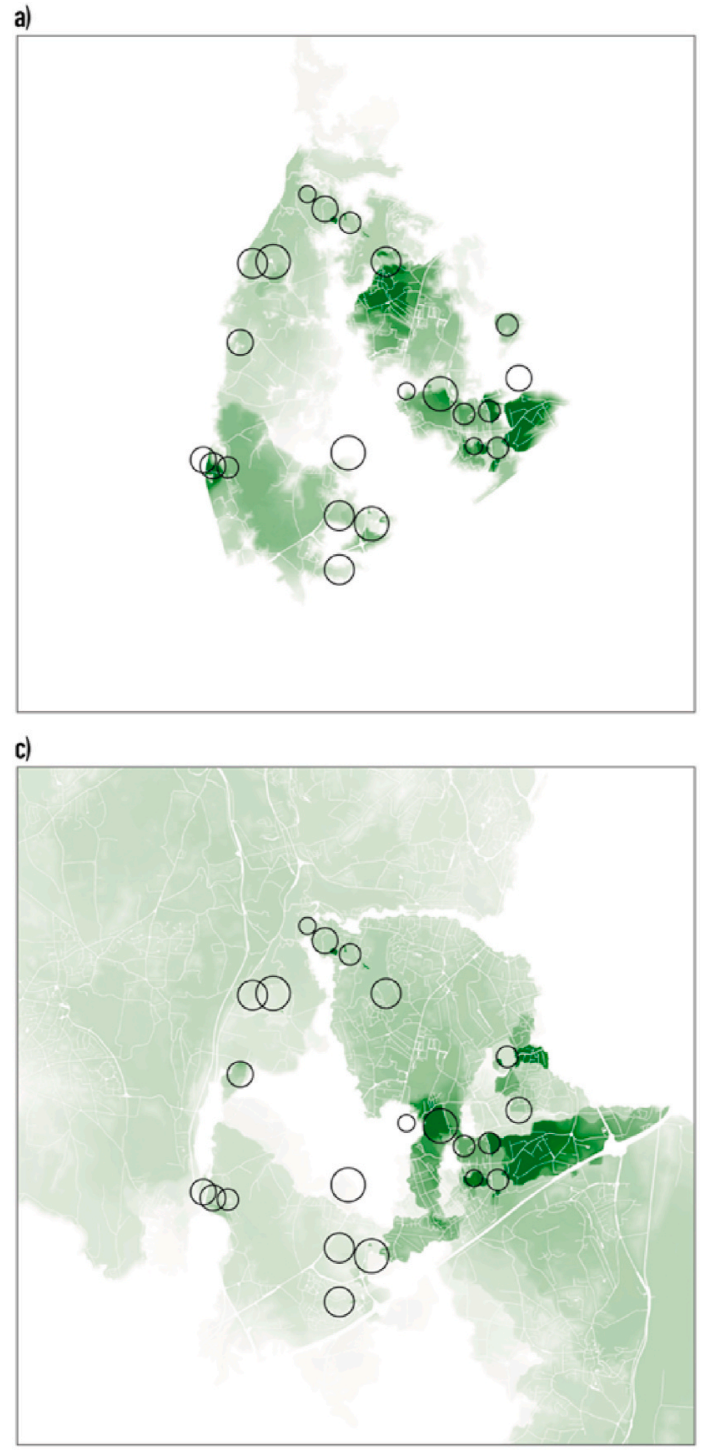

b)

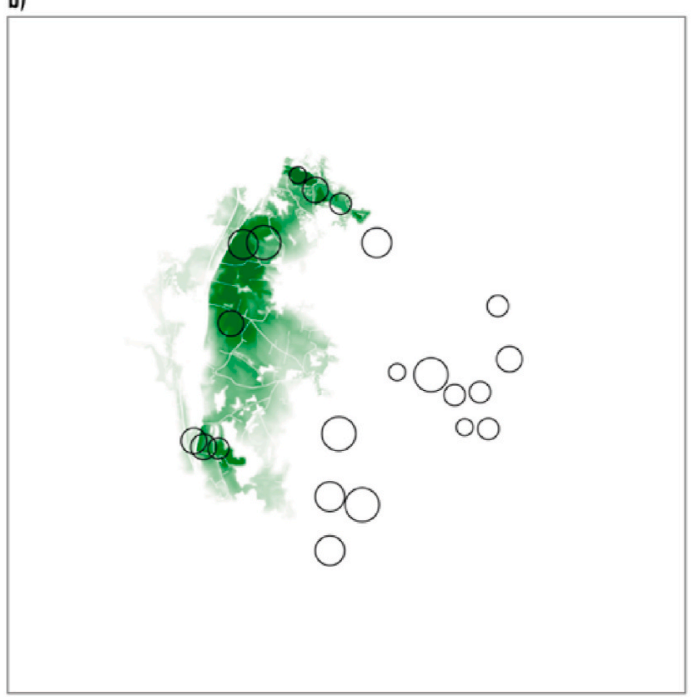

d)

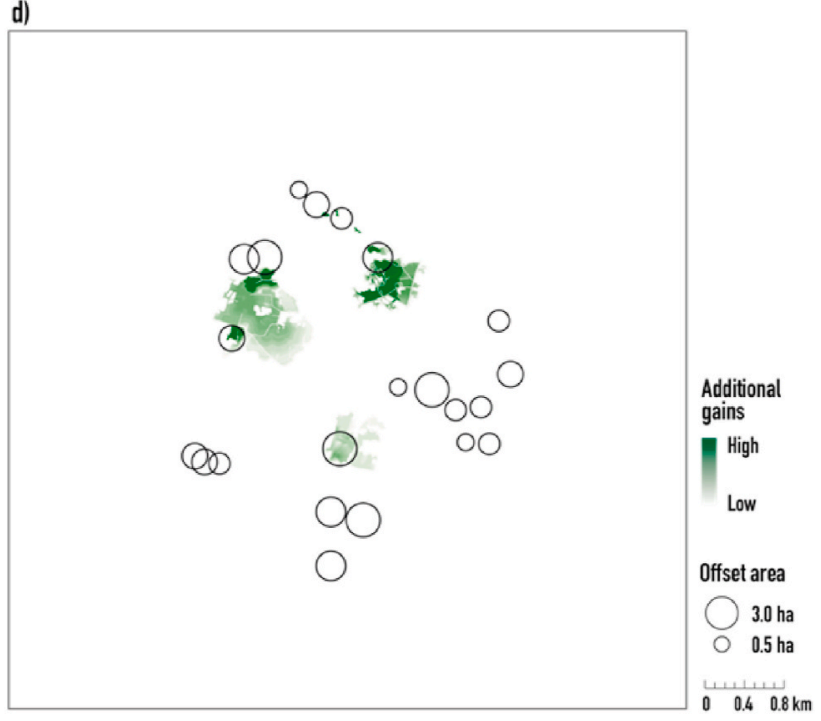

Fig. 4. Spatialization of the additional gains for (a) terrestrial mammals (red squirrel), (b) birds (spotted flycatcher), (c) chiropterans (lesser noctule) and (d) amphibians (fire salamander). Black circles represent the 22 initial biodiversity offset sites in the suburbs of Lyon used in the analysis (see Section 2.1). (For interpretation of the references to colour in this figure legend, the reader is referred to the Web version of this article.)

Finally, models based on graph theory provide interesting leads to implement biodiversity offsets by contributing to preserving biodiversity and the functionality of natural environments (Foltête, 2019). But we can note two major limitations: they are only based on the availability of spatially explicit data on species' habitat and their uncertainty is rarely assessed (Gippoliti and Battisti, 2017; but see Foltête et al., 2020). Therefore, even if our understanding of connectivity is improved by modelling approaches, we will still need to collect field data, on species behavior, habitat quality and demography (Kool et al., 2013). Many important habitat attributes for species are not available as spatially explicit data or at an appropriate scale, it therefore seems inevitable to cross the models results with expert opinions (naturalist, NGOs, managers of natural areas and other partners).

\subsection{Implications and opportunities for the NNL objective}

Adopting a landscape approach to meet the NNL (No Net Loss) objective has implications for ecological equivalent assessment (Bergès et al., 2020; Quétier and Lavorel, 2011). This new perspective on biodiversity conservation should enable later assessment (i.e., when sizing biodiversity offset measures) of whether the gains from the biodiversity offset carried out by developers are proportionate to the effects of their development projects. To assess this, stakeholders should use the Equivalent Connectivity index, EC (Saura et al., 2011), to be applicable to the mitigation hierarchy (see for example Bergès et al., 2020; Tarabon et al., 2019b; Tarabon et al., 2020). EC is a quantitative, spatially explicit and ecologically relevant metric both for species sensitive to fragmentation and for those with habitat 'amounts' requirements (De Camargo et al., 2018).

\section{Conclusion}

The goal of this paper was to investigate the relevance of pooling and planning of biodiversity offsets within spatially and ecologically coherent areas. The choice of biodiversity offset sites and measures, and their management method, should no longer be based solely on the intrinsic potential of each biodiversity offset site, but should also take the whole ecological network into account.

In France, local authorities now have greater responsibility for urban and environmental planning (due to recent European and French regulatory reforms). Thus, the anticipation and planning of biodiversity offsets can be a real decision-making lever at the heart of territorial 

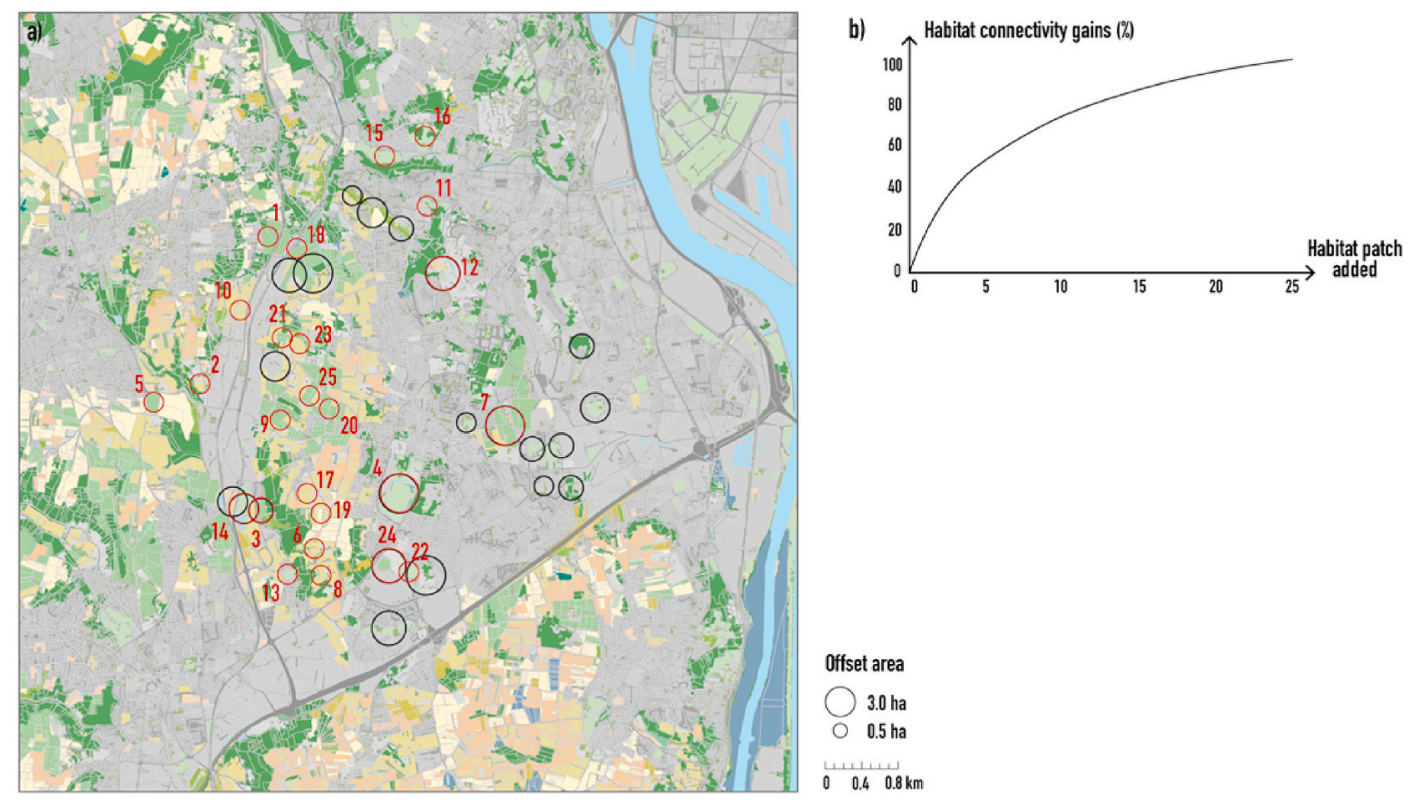

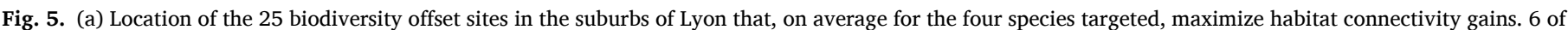

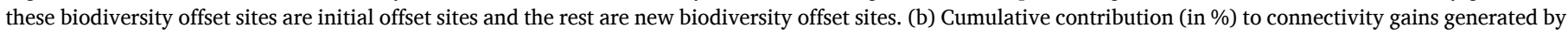
these 25 selected $\mathrm{BO}$.

organization strategies. Being anticipated upstream, biodiversity offsetting could be integrated into territorial planning and town planning tools (Martin and Brumbaugh, 2013), and find its place in the territories without getting sidelined. Hence, early anticipation of biodiversity offset sites and the various stakeholders could 1) limit the well-known administrative and economic hurdles (access to land, dispersion of biodiversity offset sites generating more numerous and more complex studies, monitoring and controls, etc. (Scemama and Levrel, 2013), and 2) contribute to preserving biodiversity and the functionality of natural environments while ensuring better socio-economic acceptability.

\section{Authors contributions}

Simon Tarabon, Conceptualization, Methodology, Validation, Formal analysis, Writing - original draft, Reviewing and Editing, Visualization. Thierry Dutoit, Supervision. Francis Isselin-Nondedeu, Supervision, Writing - original draft, Reviewing and Editing.

\section{Declaration of competing interest}

The authors declare that they have no known competing financial interests or personal relationships that could have appeared to influence the work reported in this paper.

\section{Acknowledgements}

We thank the Association for Research and Technology (ANRT) funded by the Ministry for Higher Education and Research, Fabrice Vullion and Fabienne Theuriau (Soberco Environnement) for funding and involvement under the CIFRE agreements ( ${ }^{\circ}$ 2016/1378), and Marjorie Sweetko for revising the English of the manuscript.

\section{References}

Arthur, L., Lemaire, M., 2009. Bats of France, Belgium, Luxembourg and Switzerland, second ed. Biotope Editions.

Avon, C., Bergès, L., 2016. Prioritization of habitat patches for landscape connectivity conservation differs between least-cost and resistance distances. Landsc. Ecol. 31, $1551-1565$.

Beier, P., Brost, B., 2010. Use of land facets to plan for climate change: conserving the arenas, not the actors. Conserv. Biol. 24, 701-710.
Bekessy, S.A., Wintle, B.A., Lindenmayer, D.B., Mccarthy, M.A., Colyvan, M., Burgman, M.A., Possingham, H.P., 2010. The biodiversity bank cannot be a lending bank. Conserv. Lett. 3, 151-158.

Bergès, L., Avon, C., Bezombes, L., Clauzel, C., Duflot, R., Foltête, J.-C., Gaucherand, S., Girardet, X., Spiegelberger, T., 2020. Environmental mitigation hierarchy and biodiversity offsets revisited through habitat connectivity modelling. J. Environ. Manag. 256, 109950.

Bergsten, A., Zetterberg, A., 2013. To model the landscape as a network: a practitioner's perspective. Landsc. Urban Plan 119, 35-43.

Bezombes, L., Gaucherand, S., Spiegelberger, T., Gouraud, V., Kerbiriou, C., 2018. A set of organized indicators to conciliate scientific knowledge, offset policies requirements and operational constraints in the context of biodiversity offsets. Ecol. Indica 93, 1244-1252.

Bezombes, L., Kerbiriou, C., Spiegelberger, T., 2019. Do biodiversity offsets achieve No Net Loss? An evaluation of offsets in a French department. Biol. Conserv. 231, 24-29.

Bigard, C., Pioch, S., Thompson, J.D., 2017. The inclusion of biodiversity in environmental impact assessment: policy-related progress limited by gaps and semantic confusion. J. Environ. Manag. 200, 35-45.

Bigard, C., Thiriet, P., Pioch, S., Thompson, J.D., 2020. Strategic landscape-scale planning to improve mitigation hierarchy implementation: an empirical case study in Mediterranean France. Land Use Pol. 90, 104286.

Boisvert, V., 2015. Conservation banking mechanisms and the economization of nature: an institutional analysis. Ecosyst. Serv 15, 134-142.

Bull, J.W., Strange, N., 2018. The global extent of biodiversity offset implementation under no net loss policies. Nat. Sustain 1, 790.

Bull, J.W., Gordon, A., Watson, J.E., Maron, M., 2016. Seeking convergence on the key concepts in 'no net loss' policy. J. Appl. Ecol. 53, 1686-1693.

Carreras Gamarra, M.J., Lassoie, J.P., Milder, J., 2018. Accounting for no net loss: critical assessment of biodiversity offsetting metrics and methods. J. Environ. Manag. 220, 36-43.

Chaurand, J., Bigard, C., Vanpeene-Bruhier, S., Thompson, J.D., 2019. Articulating the green and blue corridor policy and the mitigation hierarchy: complementarities and limits for an effective biodiversity conservation in France. VertigO 19.

Clauzel, C., Bannwarth, C., Foltête, J.-C., 2015. Integrating regional-scale connectivity in habitat restoration: an application for amphibian conservation in eastern France. J. Nat. Conserv. 23, 98-107.

Correa Ayram, C.A., Mendoza, M.E., Etter, A., Salicrup, D.R.P., 2016. Habitat connectivity in biodiversity conservation: a review of recent studies and applications. Prog. Phys. Geogr. 40, 7-37.

CRENAM, 2011. Identifying potential biodiversity reservoirs. IPAMAC project., France Ecological networks of the Massif Central project 55.

Crooks, K.R., Sanjayan, M., 2006. Connectivity Conservation. Cambridge University Press.

Crossman, N.D., Bryan, B.A., Ostendorf, B., Collins, S., 2007. Systematic landscape restoration in the rural-urban fringe: meeting conservation planning and policy goals. Biodivers. Conserv. 16, 3781-3802.

Dalang, T., Hersperger, A.M., 2012. Trading connectivity improvement for area loss in patch-based biodiversity reserve networks. Biol. Conserv. 148, 116-125.

De Camargo, R.X., Boucher-Lalonde, V., Currie, D.J., 2018. At the landscape level, birds respond strongly to habitat amount but weakly to fragmentation. Divers. Distrib. 24, 629-639. 
Duguet, R., Melki, F., Acemav, 2003. Amphibians of France, Belgium and Luxembourg. Biotope.

Soberco Environnement, 2019. Decision support study for implementing an offsets strategy in the project of 'Vallon des Hôpitaux' context, in the Lyon metropolis, Chaponost, p. 45.

Fahrig, L., 2017. Ecological responses to habitat fragmentation per se. Annu. Rev. Ecol. Evol. Syst. 48, 1-23.

Fey, K., Hämäläinen, S., Selonen, V., 2016. Roads are no barrier for dispersing red squirrels in an urban environment. Behav. Ecol. 27, 741-747.

Foltête, J.-C., 2019. How ecological networks could benefit from landscape graphs: a response to the paper by Spartaco Gippoliti and Corrado Battisti. Land Use Pol. 80, 391-394.

Foltête, J.-C., Clauzel, C., Vuidel, G., 2012. A software tool dedicated to the modelling of landscape networks. Environ. Model. Software 38, 316-327.

Foltête, J.-C., Girardet, X., Clauzel, C., 2014. A methodological framework for the use of landscape graphs in land-use planning. Landsc. Urban Plan 124, 140-150.

Foltête, J.-C., Savary, P., Clauzel, C., Bourgeois, M., Girardet, X., Saharoui, Y., Vuidel, G., Garnier, S., 2020. Coupling landscape graph modeling and biological data: a review. Landsc. Ecol., 1-18.

Fuentes-Montemayor, E., Watts, K., Macgregor, N.A., Lopez-Gallego, Z., Park, K.J., 2017. Species mobility and landscape context determine the importance of local and landscape-level attributes. Ecol. Appl. 27, 1541-1554.

Gasc, J.-P., Cabela, A., Crnobrnja-Isailovic, J., Dolmen, D., Grossenbacher, K., Haffner, P., Lescure, J., Martens, H., Martínez Rica, J.P., Maurin, H., 1997. Atlas of amphibians and reptiles in europe. Societas europaea herpetologica bonn, Germany.

Gelcich, S., Vargas, C., Carreras, M.J., Castilla, J.C., Donlan, C.J., 2017. Achieving biodiversity benefits with offsets: Research gaps, challenges, and needs. Ambio 46, 184-189.

Géroudet, P., Robert, L.-P., Reichel, M., Robert, P.-A., 1980. Les passereaux: des pouillots aux moineaux/avec $48 \mathrm{pl}$. dont 32 en couleur d'après les aquarelles de Léo-Paul Robert et 38 dessins de Robert Hainard, Manfred Reichel, Paul Barruel et P.-A. Robert. Delachaux \& Niestlé.

Gippoliti, S., Battisti, C., 2017. More cool than tool: equivoques, conceptual traps and weaknesses of ecological networks in environmental planning and conservation. Land Use Pol. 68, 686-691.

Gray, C.L., Hill, S.L., Newbold, T., Hudson, L.N., Börger, L., Contu, S., Hoskins, A.J., Ferrier, S., Purvis, A., Scharlemann, J.P., 2016. Local biodiversity is higher inside than outside terrestrial protected areas worldwide. Nat. Commun. 7, 1-7.

Häkkilä, M., Abrego, N., Ovaskainen, O., Mönkkönen, M., 2018. Habitat quality is more important than matrix quality for bird communities in protected areas. Ecol. Evol. 8, 4019-4030.

Hämäläinen, S., Fey, K., Selonen, V., 2018. Habitat and nest use during natal dispersal of the urban red squirrel (Sciurus vulgaris). Landsc. Urban Plann. 169, 269-275.

Haverland, M.B., Veech, J.A., 2017. Examining the occurrence of mammal species in natural areas within a rapidly urbanizing region of Texas, USA. Landsc. Urban Plann. $157,221-230$.

Hirzel, A.H., Le Lay, G., 2008. Habitat suitability modelling and niche theory. J. Appl. Ecol. 45, 1372-1381.

Hodgson, J.A., Moilanen, A., Wintle, B.A., Thomas, C.D., 2011. Habitat area, quality and connectivity: striking the balance for efficient conservation. J. Appl. Ecol. 48, 148-152.

Hooftman, D.A., Edwards, B., Bullock, J.M., 2016. Reductions in connectivity and habitat quality drive local extinctions in a plant diversity hotspot. Ecography 39, 583-592.

Kiesecker, J.M., Copeland, H., Pocewicz, A., Nibbelink, N., McKenney, B., Dahlke, J., Holloran, M., Stroud, D., 2009. A framework for implementing biodiversity offsets: selecting sites and determining scale. Bioscience 59, 77-84.

Kiesecker, J.M., Copeland, H., Pocewicz, A., McKenney, B., 2010. Development by design: blending landscape-level planning with the mitigation hierarchy. Font. Ecol. Environ 8, 261-266.

Kool, J.T., Moilanen, A., Treml, E.A., 2013. Population connectivity: recent advances and new perspectives. Landsc. Ecol. 28, 165-185.

Kormos, R., Kormos, C.F., Humle, T., Lanjouw, A., Rainer, H., Victurine, R., Mittermeier, R.A., Diallo, M.S., Rylands, A.B., Williamson, E.A., 2014. Great apes and biodiversity offset projects in Africa: the case for national offset strategies. PLoS One 9.

Kujala, H., Whitehead, A.L., Morris, W.K., Wintle, B.A., 2015. Towards strategic offsetting of biodiversity loss using spatial prioritization concepts and tools: a case study on mining impacts in Australia. Biol. Conserv 192, 513-521.

Le Roux, M., Redon, M., Archaux, F., Long, J., Vincent, S., Luque, S., 2017. Conservation planning with spatially explicit models: a case for horseshoe bats in complex mountain landscapes. Landsc. Ecol. 32, 1005-1021.

Le Saout, S., Hoffmann, M., Shi, Y., Hughes, A., Bernard, C., Brooks, T.M., Bertzky, B., Butchart, S.H., Stuart, S.N., Badman, T., 2013. Protected areas and effective biodiversity conservation. Science 342, 803-805.

Letourneau, A., Thompson, J., 2014. Annexe au SRCE Languedoc-Roussillon. Methodological Note for Identifying Areas Important for the Biodiversity and Ecological Continuities Conservation in Languedoc Region. DREAL-Région LR, Montpellier.

Levrel, H., Scemama, P., Vaissière, A.-C., 2017. Should we be wary of mitigation banking? Evidence regarding the risks associated with this wetland offset arrangement in Florida. Ecol. Econ. Times 135, 136-149.

Maron, M., Hobbs, R.J., Moilanen, A., Matthews, J.W., Christie, K., Gardner, T.A., Keith, D.A., Lindenmayer, D.B., McAlpine, C.A., 2012. Faustian bargains? Restoration realities in the context of biodiversity offset policies. Biol. Conserv. 155, 141-148.
Maron, M., Ives, C.D., Kujala, H., Bull, J.W., Maseyk, F.J., Bekessy, S., Gordon, A., Watson, J.E., Lentini, P.E., Gibbons, P., 2016. Taming a wicked problem: resolving controversies in biodiversity offsetting. Bioscience 66, 489-498.

Maron, M., Brownlie, S., Bull, J.W., Evans, M.C., von Hase, A., Quétier, F., Watson, J.E., Gordon, A., 2018. The many meanings of no net loss in environmental policy. Nat. Sustain. Times 1, 19.

Martin, S., Brumbaugh, R., 2013. Defining service areas for wetland mitigation: an overview. Wetlands Newsletter 35, 9.

May, J., Hobbs, R.J., Valentine, L.E., 2017. Are offsets effective? An evaluation of recent environmental offsets in Western Australia. Biol. Conserv. 206, 249-257.

McGarigal, K., Cushman, S., 2005. The gradient concept of landscape structure [Chapter 12]. In: Wiens, John A., Moss, Michael R. (Eds.), Issues and Perspectives in Landscape Ecology. Cambridge University Press, pp. 112-119, 112-119.

McKenney, B.A., Kiesecker, J.M., 2010. Policy development for biodiversity offsets: a review of offset frameworks. Environ. Manag. 45, 165-176.

Mimet, A., Clauzel, C., Foltête, J.-C., 2016. Locating wildlife crossings for multispecies connectivity across linear infrastructures. Landsc. Ecol. 31, 1955-1973.

Moilanen, A., 2013. Planning impact avoidance and biodiversity offsetting using software for spatial conservation prioritisation. Wildl. Res. 40, 153-162.

Moilanen, A., Laitila, J., 2016. Indirect leakage leads to a failure of avoided loss biodiversity offsetting. J. Appl. Ecol. 53, 106-111.

Moreno-Mateos, D., Power, M.E., Comín, F.A., Yockteng, R., 2012. Structural and functional loss in restored wetland ecosystems. PLoS Biol. 10, e1001247.

Naimi, B., Hamm, N.A., Groen, T.A., Skidmore, A.K., Toxopeus, A.G., 2014. Where is positional uncertainty a problem for species distribution modelling? Ecography 37, 191-203.

Newbold, T., Hudson, L.N., Arnell, A.P., Contu, S., De Palma, A., Ferrier, S., Hill, S.L., Hoskins, A.J., Lysenko, I., Phillips, H.R., 2016. Has land use pushed terrestrial biodiversity beyond the planetary boundary? A global assessment. Science 353, 288-291.

Persson, J., Larsson, A., Villarroya, A., 2015. Compensation in Swedish infrastructure projects and suggestions on policy improvements. Nat. Conserv. 11, 113.

Pouzols, F.M., Burgman, M.A., Moilanen, A., 2012. Methods for allocation of habitat management, maintenance, restoration and offsetting, when conservation actions have uncertain consequences. Biol. Conserv. 153, 41-50.

Quétier, F., Lavorel, S., 2011. Assessing ecological equivalence in biodiversity offset schemes: key issues and solutions. Biol. Conserv. 144, 2991-2999.

Rayfield, B., Fortin, M.-J., Fall, A., 2011. Connectivity for conservation: a framework to classify network measures. Ecology 92, 847-858.

Rayfield, B., Pelletier, D., Dumitru, M., Cardille, J.A., Gonzalez, A., 2016. Multipurpose habitat networks for short-range and long-range connectivity: a new method combining graph and circuit connectivity. Methods Ecol. Evol. 7, 222-231.

Rogeon, G., Sordello, R., 2012. Bibliographic synthesis on the life traits of the Gray Flycatcher (Muscicapa striata (Pallas, 1764) relating to its movements and its needs for ecological continuity. Muséum national d'Histoire Naturelle.

Sahraoui, Y., Foltête, J.-C., Clauzel, C., 2017. A multi-species approach for assessing the impact of land-cover changes on landscape connectivity. Landsc. Ecol. 32, 1819-1835.

Santini, L., Saura, S., Rondinini, C., 2016. A composite network approach for assessing multi-species connectivity: an application to road defragmentation prioritisation. PloS one 11, e0164794.

Saura, S., Bodin, Ö., Fortin, M.J., 2014. Stepping stones are crucial for species' longdistance dispersal and range expansion through habitat networks. J. Appl. Ecol. 51, $171-182$.

Saura, S., de la Fuente, B., 2017. Connectivity as the amount of reachable habitat: conservation priorities and the roles of habitat patches in landscape networks. Learning Landsc. Ecol. Springer, pp. 229-254.

Saura, S., Pascual-Hortal, L., 2007. A new habitat availability index to integrate connectivity in landscape conservation planning: comparison with existing indices and application to a case study. Landsc. Urban Plan 83, 91-103.

Saura, S., Torne, J., 2009. Conefor Sensinode 2.2: a software package for quantifying the importance of habitat patches for landscape connectivity. Environ. Model. Software 24, 135-139.

Saura, S., Estreguil, C., Mouton, C., Rodríguez-Freire, M., 2011. Network analysis to assess landscape connectivity trends: application to European forests (1990-2000. Ecol. Indicat. 11, 407-416.

Scemama, P., Levrel, H., 2013. The emergence of the US wetland compensation market: impacts on organizational patterns and transaction characteristics. Rev. Écon. Polit. 123, 893-924.

Scolozzi, R., Geneletti, D., 2012. A multi-scale qualitative approach to assess the impact of urbanization on natural habitats and their connectivity. Environ. Impact. Assessment 36, 9-22.

Shannon, C.E., 1948. A mathematical theory of communication. Bell system technical journal 27, 379-423.

Simmonds, J.S., Sonter, L.J., Watson, J.E., Bennun, L., Costa, H.M., Dutson, G., Edwards, S., Grantham, H., Griffiths, V.F., Jones, J.P., 2019. Moving from biodiversity offsets to a target-based approach for ecological compensation. Conserv. Lett., e12695.

Stevens, D.K., Anderson, G.Q., Grice, P.V., Norris, K., 2007. Breeding success of Spotted Flycatchers Muscicapa striata in southern England-is woodland a good habitat for this species? Ibis 149, 214-223.

Tambosi, L.R., Martensen, A.C., Ribeiro, M.C., Metzger, J.P., 2014. A framework to optimize biodiversity restoration efforts based on habitat amount and landscape connectivity. Restor. Ecol. 22, 169-177. 
Tarabon, S., Bergès, L., Dutoit, T., Isselin-Nondedeu, F., 2019a. Environmental impact assessment of development projects improved by merging species distribution and habitat connectivity modelling. J. Environ. Manag. 241, 439-449.

Tarabon, S., Bergès, L., Dutoit, T., Isselin-Nondedeu, F., 2019b. Maximizing habitat connectivity in the mitigation hierarchy. A case study on three terrestrial mammals in an urban environment. J. Environ. Manag. 243, 340-349.

Tarabon, S., Calvet, C., Delbar, V., Dutoit, T., Isselin-Nondedeu, F., 2020. Integrating a landscape connectivity approach into mitigation hierarchy planning by anticipating urban dynamics. Landsc. Urban Plann. 202, 103871.

Team, R., 2017. R: a language and environment for statistical computing. Austria: R Foundation for Statistical Computing, Vienna, 2016.

Thirion, J.-M., Vollette, J., Mathé, E., Landry, G., Gironnet, E., 2014. An original littoral population of spotted salamander Salamandra salamandra subsp. terrestris (Linnaeus, 1758), Annales de la Société des Sciences Naturelles de la CharenteMaritime, pp. 529-531.

UICN, 2013. Protected Natural Areas in France: a Plurality of Tools at the Service of Biodiversity Conservation. Paris, p. 44.
Urban, D.L., Minor, E.S., Treml, E.A., Schick, R.S., 2009. Graph models of habitat mosaics. Ecol. Lett. 12, 260-273.

van Teeffelen, A.J., Opdam, P., Wätzold, F., Hartig, F., Johst, K., Drechsler, M., Vos, C.C., Wissel, S., Quétier, F., 2014. Ecological and economic conditions and associated institutional challenges for conservation banking in dynamic landscapes. Landsc. Urban Plann. 130, 64-72.

Walker, S., Brower, A.L., Stephens, R.T., Lee, W.G., 2009. Why bartering biodiversity fails. Conserv. Lett. 2, 149-157.

Weissgerber, M., Roturier, S., Julliard, R., Guillet, F., 2019. Biodiversity offsetting: certainty of the net loss but uncertainty of the net gain. Biol. Conserv. 237, 200-208.

Wende, W., Tucker, G.-M., Quétier, F., Rayment, M., Darbi, M., 2018. Biodiversity offsets: European perspectives on No net loss of biodiversity and ecosystem services. Springer.

Wintle, B.A., Kujala, H., Whitehead, A., Cameron, A., Veloz, S., Kukkala, A., Moilanen, A., Gordon, A., Lentini, P.E., Cadenhead, N.C., 2019. Global synthesis of conservation studies reveals the importance of small habitat patches for biodiversity. Proc. Natl. Acad. Sci. Unit. States Am. 116, 909-914. 